\title{
The Experience and Enlightenment of “Three-Dimensional Integration" Talent Training Model
}

\author{
Kaiju Hu \\ Business School, Guizhou Minzu University, Guiyang, China
}

\begin{abstract}
In this paper, the design ideas and connotations of the "three-dimensional integration" talent training model, as well as the specific implementation in the curriculum system, ideological and political education, student second classroom, student social practice, national cultural inheritance and innovation, etc. are introduced. The implementation effect achieved through the "three-dimensional integration" talent training model illustrates the feasibility of the model and the idea of emphasizing school running and optimizing the talent training model; innovating training goals, deeply integrating teacher and student classrooms; transforming management concepts and establishing synergy education platform and other enlightenment.
\end{abstract}

Keywords: Three-dimensional integration, Talent training, Experience.

\section{Introduction}

Higher education has been exploring diversified integration and collaborative cooperation in our country. Especially in recent years, from the central to the local, from the government to colleges and universities, all efforts have been made to promote the development of school-enterprise cooperation to a deeper level and higher quality, and it has achieved remarkable results. The results show that the trend of diversified integration and synergy in higher education has been recognized by all parties [1]. According to the education policy of the party and the country, Guizhou Minzu University actively follows the law of higher education development, adheres to the school purpose of based in Guizhou Province, serving ethnic regions, serving national strategies and special needs, actively exploring new talent training models, and further refining the school's talents cultivate positioning. That is to "train high-quality applied talents with perseverance in faith, good moral character, humanistic spirit, scientific spirit, national unity spirit, rich knowledge, and strong skills". The concept of "three-dimensional integration" as a leader in talent training was determined, and it played an active role in the process of talent training.

\section{The Experience of "Three-dimensional Integration" Talent Training Model}

\subsection{Design Ideas and Connotation}

Humanistic spirit not only pays attention to the value and meaning of life, but also pays attention to the overall destiny of mankind. Universities are important places for inheriting and disseminating excellent culture, and they are also important positions for nurturing and creating new knowledge, new ideas, and new theories. In cultivating talents, guarding ideas, inheriting civilization, and innovating theories, they should play an important role in cultivating and promoting the humanistic spirit and positive effect. Universities pay attention to the guidance of spiritual home consciousness in the process of talent training, which is conducive to the formation of universal social identity for the spiritual home shared by the Chinese nation. As a choice for the construction of the spiritual home, the leading position of the scientific spirit in the value rationality of the spiritual home cannot be ignored. Only by establishing a scientific spirit, high-quality talents can use scientific thinking and awareness to build a beautiful spiritual home for mankind. In addition, it is the duty of every citizen to consciously maintain national unity and promote the common development and prosperity of the nation. Contemporary college students are the outstanding builders of the motherland and the hope of the nation. Universities cultivate their national unity spirit, which has become an inevitable requirement for the development of today's legalized society. As one of the earliest ethnic colleges founded in New China, the students of Guizhou Minzu University mainly come from ethnic minorities and ethnic regions. These students from different regions are inseparable from each other. The Han nationality cannot be separated from the ethnic minorities, the minority nationalities cannot be separated from the Han nationality, and the various ethnic minorities cannot be separated from each other. In addition to students with a spirit, truth-seeking and scientific spirit, we must also train students with a spirit of national unity. It is precisely based on the accurate judgment of the current educational situation and background, through exploration and practice, that Guizhou Minzu University has formally formed a "three-dimensional integration" talent training model.

"Three-dimensional integration" is the deep integration of humanistic spirit, scientific spirit, and national unity spirit. The core of the humanistic spirit is seeking goodness and beauty, the core of scientific spirit is seeking truth and seeking truth, and the core of the spirit of national unity is seeking harmony and common ground. Identification, identification with the Chinese nation, identification with Chinese culture, identification with the Communist Party of China, identification with socialism with Chinese characteristics. The "three-dimensional integration" talent training model is to 
integrate the three spirits into the whole process of running a school and training talents. In running schools and governing schools, we must adhere to the people-oriented service concept, the truth-seeking and pragmatic work style, and the overall awareness of maintaining national unity in the development of the school's various undertakings, teaching, management and services; Seeking truth as the theme, humanistic education is based on seeking goodness, and cultivate high-quality successors of the socialist cause with humanistic feelings, sound personality, advocating science, exploring truth, focusing on innovation, dedication to society, and patriotism and national unity. At the college level, the talent training plan, the first and second classrooms, collaborative education, and social practice all deeply integrate the three spirits, embodying "all-round education, all-round education, and whole-process education".

\subsection{Implementation Plan}

\subsubsection{Curriculum system.}

The school adheres to the concept of "three-dimensional integration", strengthens advantages, condenses characteristics, strengthens the construction of the curriculum system, builds ability-based, interdisciplinary integration, equal emphasis on general education and professional education, adapts to the training of applied talents, and emphasizes humanistic feelings and scientific literacy, Practical application and individual development, application-oriented curriculum system and "special demand" talent training model that meet the needs of regional economic and social development. Among them, 31 humanities and social science courses, 11 natural science courses, 8 art courses, 8 economics and management law and educational psychology courses, and 26 online general education courses have been opened in the quality development courses for college students. The humanistic and scientific spirit of the students.

\subsubsection{Ideological and political education work}

In ideological and political work, adhere to the deep integration and implementation of the humanistic spirit, scientific spirit and national unity spirit, with ideal and belief education as the core, patriotism education as the main line, scientific and humanistic quality education as the goal, and national unity education as the core. Focus on the basic ethics education as the foundation, the basic ethics education as the foundation, and use the extracurricular activities as the platform to carry out educational activities with rich content and various forms in a step-by-step and organized manner. Organizing teams to carry out summer social practice activities of "Three Going to the Countryside" in Qiandongnan Prefecture and other places, the majority of students have firm ideals and beliefs. Use the moral lecture hall to carry out in-depth moral education, and hold quality moral lectures every month. Carry out various activities such as "National Unity and Family", "Colorful Guizhou Tourism Image Ambassador Selection", "Five Identity Essay Competition", "Colorful Guizhou Photography Exhibition" and other activities to strengthen the national unity of teachers and students. The ethnic minority singing and dancing evening party where elegant art enters the campus was held, and the "Five Ones" project of inheriting ethnic culture was carried out to guide teachers and students of all ethnic groups to firmly establish the idea of "three inseparable" and strengthen the concept of "five identities".

\subsubsection{The second classroom for students}

Make full use of Confucian Schools, libraries, campus academic lectures, college student science and technology competitions, party schools, league schools and other positions to carry out humanistic and scientific spirit education. Taking advantage of the location advantages of Confucian School and Guizhou University for Nationalities, students are encouraged to listen to lectures in Confucian School. Each 6 lectures counts 1 credit, and a maximum of 30 lectures counts for 5 credits. Carried out scholarly care lectures, with an audience of tens of thousands. The topics of the lectures covered literature, history, philosophy, art and natural sciences. The scholarly care lectures have become an important platform for college students to shape the humanistic, scientific and national unity spirit. The new district and other units jointly build and cooperate to establish incentives, guidance, project establishment, support, and incubation systems for college students' extracurricular scientific and technological activities, provide a broad stage for students to carry out extracurricular scientific and technological activities, and actively create a good atmosphere of advocating science, pursuing excellence, and daring to create. The scientific spirit of the students.

\subsubsection{Student social practice}

Focusing on the needs of Guizhou's economic and social development and helping poverty alleviation, organize students to carry out social practice and voluntary service work, go deep into poverty-stricken ethnic minority areas where basic education is weak, education resources are scarce, and left-behind children are relatively concentrated, and provide compulsory education support, community services, and orphan support Activities such as assistance to the disabled, legal aid, agricultural technology promotion, cultural performances, field surveys of ethnic and folk culture and rural surveys, establishment of ethnic art practice bases, etc., to enhance students' sense of social responsibility, enhance ethnic sentiment, and cultivate humanistic feelings and science.

\subsubsection{Inheritance and innovation of national culture}

Guizhou's colorful ethnic and folk culture provides abundant fertile ground and unlimited space for the training of talents in the school. For a long time, teachers and students have used vacations to travel through mountains and rivers to investigate, sort out, and research ethnic folk cultural resources in ethnic areas, and have achieved remarkable results. The various achievements have had a significant impact in the academic and political circles, and have made important contributions 
to promoting the promotion of national folk culture to the most distinctive Guizhou mark, Guizhou characteristics, and Guizhou symbol.

\subsection{Implementation Effect}

The school has been awarded the "National Model Unit for National Unity and Progress" five times, and has become a demonstration base for national unity and progress in our province. Through national culture into teaching materials, classrooms, and campuses, students will be cultivated to love their hometowns, ethnic regions, and ethnic cultures, so that they can establish a correct outlook on the world, life, values, nationality and career choices, and cultivate national unity The spirit finally achieves the purpose of entering the mind. Through the "Four Entrances" of national culture, the majority of students have their own characteristics and cultivated a large number of high-quality applied talents with solid professional foundation, significant regional and cultural characteristics, humanistic spirit, scientific spirit and national unity spirit. The humanistic spirit, scientific spirit, and national unity spirit are deeply integrated into the ideological and political education work, and an excellent style of study and teaching has been formed. First of all, teachers earnestly perform their duties and their teaching and research capabilities have been improved. In the past two years, it has won 55 educational reform projects at or above the provincial level; 16 first prizes, 27 second prizes, and 45 third prizes were selected for school-level teacher classroom teaching competitions; 10 school-level teaching achievement awards were selected. Secondly, the library has become an important place for students to study independently. In 2020 alone, the school library has attracted more than 800,000 students, held more than 130 cultural and academic activities, and participated in more than 20,000 readers. The school has won the honorary title of "Advanced Unit for National Reading" for two consecutive years. Once again, the student subject competition has achieved outstanding results.

Through the establishment of student activity centers, innovating ideas for ideological and political education, strengthening the construction of school spirit and learning style, and inheriting excellent national culture, combined with professional education, the school continuously cultivates and enhances the humanistic, scientific and national unity spirit of students. In recent years, Guizhou Minzu University has organized training courses for ethnic cadres, and successively organized general political classes, ethnic policy research classes, cadre rotation political training, cadre rotation training cultural classes, as well as heads of ethnic minorities, ethnic township chiefs, ethnic school principals, ethnic women Training courses for cadres, ethnic minority rural cadres, ethnic minority "bilingual" talents, inheritors of intangible cultural heritage, etc., have trained nearly 20,000 ethnic cadres, ethnic "bilingual" talents, and inheritors of ethnic folk culture. Since the establishment of the school, the school has trained and delivered more than 100,000 professionals of various types to the society. More than $80 \%$ of them have worked at the grassroots level and in ethnic areas, and they have become the backbone of promoting economic construction and social development in ethnic areas.

\section{Enlightenment of "Three-dimensional Integration" Talent Training Model}

\subsection{Emphasize the Concept of Running a School and Optimize the Talent Training Model}

The general goal of undergraduate talent training is to "train high-quality applied talents with perseverance in belief, good moral character, humanistic spirit, scientific spirit, national unity spirit, rich knowledge, and strong skills", and the "three-dimensional integration" will be upgraded to the school The school-running philosophy of the school is run through a variety of methods and means in the school management and personnel training. In the process of talent training, we adhere to the practice concepts of "three inseparable" and "four dimensions in one". Not only does it emphasize that "the Han cannot be separated from the ethnic minorities, and the ethnic minorities cannot be separated from the Han, but also among the ethnic minorities. The sense of national unity that is not open, and the school-running philosophy of "education is the foundation of school building, quality is the key to building a school, talents are the pillars of a strong school, and characteristics are the way to build a school" is integrated into teaching and educating people. All links promote the high integration of students' humanistic spirit, scientific spirit and national unity spirit.

\subsection{Innovative Training Goals and Deep Integration of Teacher and Student Classrooms}

The "three-dimensional integration" emphasizes the deep integration of humanistic, scientific and national unity spirit. Through the learning of humanistic, scientific and national unity knowledge, and through cultural exchange activities of various nationalities, students of various nationalities have built up the idea of a Chinese national community. It has enhanced the unity and progress of students of all ethnic groups, and achieved a high degree of unity between the school-running philosophy, the morality and the socialist core values.

The school continuously optimizes the talent training program and sets up four major curriculum modules to correspondingly cultivate the humanistic spirit, scientific spirit and national unity spirit of students. Make full use of Confucian Schools, libraries, academic lectures, science and technology competitions, party schools, league schools and other positions to carry out humanistic and scientific spirit education, and use the deep integration of "first classroom" and "second classroom" as the "three-dimensional integration" An important path for the implementation of ideas.

\subsection{Change Management Concepts and Establish Collaborative Education Cooperation}

In order to achieve the ternary integration of talent training and make all parties win-win, colleges and universities need 
to start reforms from management concepts, talent training goals, and faculty. First of all, colleges and universities should recognize and follow the trend of ternary integration and synergy, establish an open and inclusive school-running concept, and realize the transformation from traditional knowledge transfer to realistic talent training, from the traditional graduation and enrollment to employment-oriented transformation, and actively contact and integrate into social practice. Secondly, universities should actively invite local governments, business units, social organizations, and parents to participate in the formulation of talent training goals, so that the talent training model can not only adapt to the growth pace of local universities, but also meet the needs of regional social development. Finally, as teachers are direct actors in talent training, local colleges and universities need to stimulate teachers' enthusiasm to participate in diversified and collaborative talent training. They should innovate the personnel management system of colleges and universities, break the barriers to personnel exchanges between universities and enterprises, and unblock the participation of external personnel in college talent training. The cooperative channel allows teachers to participate in enterprise production, research and development and other activities, and improve the practicality of university teaching. In addition, industry associations play an active role in enhancing industry -university cooperation and co-cultivating talents. It helps individual enterprises connect with local universities and meets the needs of universities for student employment and enterprises for professional talents [2].

\section{Conclusion}

Nowadays, higher education is facing the development trend of popularization, marketization and internationalization. Reforming and innovating the talent training model and cultivating high-quality applied compound talents is a topic of common concern for all universities [3]. Guizhou Minzu University has brought some experience and enlightenment to the talent training model of "three-dimensional integration". Next, we will further strengthen the in-depth cooperation with well-known enterprises, improve the compound ability of talents, and actively explore new models and long-term talent training for ethnic universities.

\section{References}

[1] Xinqin Wang. Research on "Dual integration and double guarantee" training mode of electromechanical compound talents of higher vocational colleges[J]. Experimental Technology and Management, 2018, 35(8): 163-166.

[2] Rui Huang, Tongrui Yu. Research on the talent cultivation model of local universities from the perspective of multiple integration and synergy $[\mathrm{J}]$. Journal of Changchun Institute of Education, 2018, 34(12): 10-12.

[3] Zhongmin Wang, Xiaochuan Dong, Weihua Wu, et al. Exploration of ternary system talent training model from the perspective of industry and education integration and school-enterprise cooperation[J]. Vocational Education Research, 2019(6): 15-18. 